OROSZ Nikolett', TÓTHNÉ TÓTH Tünde', VARGÁNÉ GYURÓ Gyöngyi', NÁBRÁDI Tibor Zsoltné', HEGEDÜSNÉ SOROSI Klára', NAGY Zsuzsa', RIGÓ Éva', KAPOSI Ádám', NAGY Attila Csaba², GÖMÖRI Gabriella'

'Debreceni Egyetem Klinikai Központ, Kórházhigiénés Osztály, Debrecen; ²Debreceni Egyetem, Népegészségügyi Kar, Debrecen

E-mail: orosz.nikolett@med.unideb.hu

\title{
Területen szerzett infekciók a Debreceni Egyetem Klinikai Központ Nagyerdei Campuson - milyen fertőzések jelentkeztek a COVID-19 mellett 2020-ban?
}

\section{Összefoglalás:}

Bár az elmúlt évtizedekben a fejlett országokban nagymértékben csökkent a fertőzések okozta morbiditás és mortalitás, az egészségügyi intézményekben detektált infekciók napjainkban is jelentős problémát okoznak. Közülük kiemelt fontossággal bírnak az ellátási területen szerzett, és a betegek által kórházakba behurcolt fertőzések. Az egészségügyi intézményekben detektált területen szerzett infekciók okozta morbiditás és mortalitás csökkentéséhez ismeretekkel szükséges rendelkeznünk azok típusairól, valamint kórokozóiról.

Vizsgálatunk célja a területen szerzett infekciók azonosítása, incidenciájának és prevalenciájának elemzése a Debreceni Egyetem Klinikai Központ Nagyerdei Campuson (DE KK NC).

Munkánk során a leggyakoribb enterális, légúti, illetve multirezisztens kórokozók okozta fertőzések adatait gyújtöttük 2020.01.01-12.31. között. Az esetekre vonatkozó adatokat a DE KK NC-n használt információs rendszerekből (Medbakter, e-MedSolution) kértük le, melyeket adatbázisban rögzítettük. Adatgyújtést követően adattisztítást, leíró statisztikai elemzést majd statisztikai analízist végeztünk.

A DE KK NC-n, a vizsgált időszakban a területen szerzett fertőzéseket 56 \%-ban multirezisztens kórokozók, 31 \%-ban enterális patogének, 13 \%-ban légúti kórokozók okozták. Az esetek korcsoportonkénti megoszlását vizsgálva kimutattuk, hogy a legtöbb infekció a 0-9 éves, valamint 60 év fölötti korcsoportokba tartozók körében fordult elő. A detektált fertőzések közül a Multirezisztens Escherichia coli (MECO; 216,89/100 000 fö), a Multirezisztens Klebsiella pneumoniae (MKLE; 125,94/100 000 fő), valamint az Influenza vírusok (127,34/100 000 fő) okozta megbetegedések száma volt a legnagyobb. A betegek lakóhelyének típusa szerint elemezve a fertőzések megoszlását megállapítottuk, hogy Campylobacter és Rotavírus infekciók között szignifikánsan nagyobb arányban voltak községben és kisvárosokban lakó betegek, míg MECO és MKLE fertőzések szignifikánsan nagyobb százalékban fordultak elő megyei jogú városokban élő személyeknél. Kimutattuk továbbá, hogy Clostridioides difficile, MECO és MKLE fertőzöttek között szignifikánsan nagyobb arányban voltak 6 napnál hosszabb kórházi ellátást igénylő betegek, míg Campylobacter, Salmonella és Rotavírus fertőzöttek között szignifikánsan nagyobb arányban fordultak elő azok, akiket kevesebb, mint 6 napig kezeltek fekvőbetegként.

Eredményeink új adatokkal szolgálhatnak a területen szerzett fertőzések epidemiológiájának megismeréséhez, valamint az általuk okozott betegségteher csökkentéséhez.

Kulcsszavak: enterális pathogén, influenza, multirezisztens kórokozó, területen szerzett infekció 